\title{
MAKNA SIMBOLIK DALAM NASKAH DRAMA CABIK KARYA MUHAMMAD IBRAHIM ILYAS
}

\author{
'Rahayu Ratna Ningsih; ${ }^{2}$ Amril Canrhas; ${ }^{3}$ Emi Agustina \\ 1,2,3 Program Studi Pendidikan Bahasa Indonesia FKIP Universitas Bengkulu
}

Abstrak

\section{Korespondensi: rahayurn1997@gmail.com}

Tujuan penelitian ini untuk mengetahui simbol dan makna simbolik cabik dalam naskah drama Cabik karya Muhammad Ibrahim llyas. Metode yang digunakan dalam penelitian ini adalah metode kualitatif, prosedur penelitian yang menghasilkan data deskriptif berupa kata-kata dari dialog yang dapat diamati. Pedekatan yang digunakan dalam penilitian ini menggunakan pendekatan semiotik untuk mengetahui simbol dan keseluruhan makna yang berhubungan dengan simbol cabik dalam naskah drama Cabik karya Muhammad Ibrahim Ilyas dengan menggunakan landasan teori Pierce. Hasil yang diperoleh dalam penelitian ini adalah ungkapan simbol yang dominan terdapat di dalam dialog yaitu,ting!, menunggu, kelam menyimpan api, api membakar percik sepi, dalam kelam ada nyala, bayi, perpisahan, dan luka. Makna simbolik 'cabik' yang terdapat di dalam naskah merupakan robeknya lembaran cerita percintaan dan prahara rumah tangga sehingga ingin berujung pada perpisahan tapi dalam keraguan yang membutuhkan waktu untuk bisa dapat memperbaiki keadaan seperti semula agar lembaran-lembaran cerita kelam dapat ditembus dengan cahaya api (pengharapan) yang begitu diharapkan tokoh Lelaki dan tokoh perempuan.

Kata Kunci: makna, simbolik, naskah Cabik

\section{Abstract}

The purpose of this research is to study the symbol and symbolic meaning of "cabik" in the "Cabik" drama scripted by Muhammad Ibrahim llyas. The method used in this study is a qualitative method, a research procedure that produces descriptive data in the form of words from dialogues that can be obtained. The approach used in this study uses semiotics to study the symbols and the overall meaning associated with the "cabik" symbol in the drama script "Cabik" by Muhammad Ibrahim Ilyas using Pierce's theoretical basis. The results obtained in this study are the dominant symbols obtained in the dialogue namely: ting! menunggu, kelam menyimpan api, api membakar percik sepi, dalam kelam ada nyala, bayi, perpisaban, dan luka. The symbolic meaning of "cabik." in the text represents the tearing of the household love and tempest story sheets wanting to end in separation but in doubt that requires time to be fixed as before so that dark stories can be penetrated with fire (hope) very much expected by male figure and woman figure.

Keywords: meaning, symbolic, "Cabik" script 


\section{PENDAHULUAN}

Seiring berkembangnya pola pikir manusia banyak mengalami perbedaan sebuah pemahaman yang sehingga merujuk pada terbentuknya suatu makna. Setiap kehidupan manusia tidak terlepas dengan makna atau pemahaman lisan maupun tulisan. Ketika seseorang melihat suatu hal yang berada dekatnya tanpa berpikir lama seseorang itu sudah mengetahui makna dari benda tersebut. Tetapi bisa saja seseorang yang lain melihat hal yang dilihat atau mendengar bunyi yang didengar tersebut dengan pemahaman yang berbeda. Hal yang dimaksud sebelumnya bersifat tanda, simbol dan makna berhubungan dengan kajian keilmuan semiotik.

Menurut (Littlejhon, 2009 : 53) Kajian semiotik tidak bisa dipisahkan dengan teori komunikasi. Tradisi semiotik terdiri atas sekumpulan teori tentang bagaimana tandatanda merepresentasikan benda, ide, keadaan, situasi, perasaan dan kondisi di luar tandatanda itu sendiri. Menurut Pierce fungsi esensial sebuah tanda adalah membuat suatu efisien, baik dalam komunikasi kita dengan orang lain, maupun dalam pemikiran dan pemahaman kita tentang dunia. Pierce sampai pada keyakinan bahwa manusia berpikir dalam tanda (Zoest, 1993 : 10). Karya sastra dengan gendre puisi, prosa, dan drama sebagian besar pengarang menyisipkan semiotik berupa tanda, kata dan kalimat yang memiliki lebih dari satu makna sehingga pembaca akan berpikir dan membaca ulang dari pemikiran pengarang yang dituliskan menjadi berupa teks (Kartini, 2017: 1).

Proses dalam penciptaan sebuah karya sastra, pengarang menerima kenyataan yang ada di sekitarnya yang dituangkan ke dalam sebuah karya. Menurut Sumardjo dan Saini dalam buku (Rokhmansyah, 2014), sastra adalah ungkapan pribadi manusia yang berupa pengalaman, pemikiran, perasaan, ide, semangat keyakinan dalam suatu bentuk gambaran konkret yang membangkitkan pesona dengan alat Bahasa. Melalui karya sastra, pembaca dapat memahami tentang keberadaan sebuah masyarakat. Misalnya kebudayaan, wawasan dalam berpikir, peristiwa sejarah dan adat istiadat serta hal-hal yang berhubungan dengan masyarakat tersebut.

Seorang pembaca ketika dihadapkan pada sebuah karya sastra khususnya drama dan menikmatinya, maka tidak sedikit pembaca menemukan kesulitan-kesulitan dalam memahami karya sastra tersebut. Drama sebagai hasil cipta sastra juga dapat berfungsi sebagai cerminan kehidupan masyarakat. Misalnya, adat istiadat, kebudayaan serta halhal yang berhubungan dengan kehidupan masyarakat serta politik.

Drama mempunyai kekhususan dibanding dengan genre puisi ataupun genre fiksi. Kekhususan drama lebih terfokus sebagai suatu karya yang lebih berorientasi kepada seni pertunjukan, dibandingkan sebagai genre sastra (Hasanuddin, 1997: 1). Menurut (Semi, 1989 : 144), drama sebagai karya sastra memiliki dimensi gerak, laku, dan ujuran. Drama dibangun dan dibentuk oleh beberapa unsur antara lain, alur, penokohan, dialog, aneka sastra kesusastraan, dan lain-lain. Dialog lebih diutamakan dalam drama. Cerita dalam drama dapat dimengerti dari dialog-dialog antar tokoh, hal inilah yang menyebabkan drama lebih menyeluruh untuk dibandingkan genre sastra lainnya.

Drama memiliki hubungan yang sangat erat dengan dialog. Drama mengutamakan pemaparan ucapan tokoh atau dialog. Dalam dialog terdapat penokohan, peristiwa, dan permasalahan yang hendak dikemukakan oleh pengarangnya. Sedikit jumlahnya tulisan yang memperlakukan naskah drama sebagai karya sastra, membuktikan bahwa naskah drama masih sering terlupakan sebagai bagian salah satu dari karya sastra. Pada umumnya orang-orang akan mengerti makna naskah drama setelah dipentaskan. 
Naskah drama ketika dipentaskan, keutuhannya sebagai sebuah karya sastra sangat diragukan dan membutuhkan penafsiran seorang sutradara terhadap naskah drama yang akan dipentaskannya serta penafsiran para pembaca maupun penonton ketika naskah drama itu ditampilkan. Drama sekarang sedikit sulit untuk dipahami, karena menjurus pada hal-hal yang sulit untuk dimengerti, memahami sebuah drama berbeda dengan memahami gendre sastra lainnya, yaitu puisi dan prosa (Yulia, 2012:3). Hal ini disebabkan karena keseluruhan bentuk diperoleh melalui dialog yang merupakan ciri khusus drama dengan simbol-simbol tertentu.

Salah satu karya sastra yang terbentuk berupa naskah drama adalah di dalam buku Dalam Tubuh Waktu karya Muhammad Ibrahim Ilyas di dalam buku tersebut terdapat tiga teks naskah drama yaitu Cabik, Pekik Sunyi dan Dendang Waktu. Dalam ketiga teks naskah drama tersebut memiliki keunikan pola cerita yang sama yaitu memainkan tanda suara sebagai penentu alur dan berperan penting dalam jalan cerita dan tiga teks naskah drama memiliki masing-masing jenis suara yang berbeda pada jalan cerita, persoalanpersoalan kemanusiaan, dan tokoh yang digunakan tidak menggunakan identitas secara spesifik seperti (Suara, Perempuan, Lelaki, Sosok, Lelaki Yang Satu, dan Lelaki Yang Lain).

Naskah drama yang pertama, naskah drama Cabik menceritakan hubungan antara tokoh perempuan dan lelaki yang memiliki siklus penjalinan cinta rasa kekecewaan dan keraguan. Naskah drama yang kedua Pekik Sunyi menceritakan adanya suatu penderitaan pada persoalan hak kemanusiaan atau peperangan. Pada jalan cerita tersebut jeritan dan hak ingin menyuarakan persoalan konflik kemanusiaan ingin dilontarkan. Yang ketiga, naskah drama berjudul Dendang Waktu yaitu ada unsur perpaduan cerita mitologi nusantara Indonesia dan mitologi Yunani. Di dalam cerita ada salah satu tokoh Lelaki Yang Satu yang mencari batu yang dikaitkan bahwa batu tersebut merupakan atas dari hukumannya yang telah ia perbuat dan mengaitkan dengan batu kutukan dari cerita malin kundang.

Di dalam dialog naskah drama Cabik banyak terdapat ungkapkan-ungkapan tokoh atau simbol-simbol yang memiliki unsur makna tersirat dan membutuhkan pemahaman yang baik karena penyebutan api di dalam dialog begitu dominan serta makna hubungannya dengan judul Cabik. Kedua, jenis dialog yang tidak hanya dijangkau secara umum tetapi ada makna lain yang perlu diketahui pemahamannya, maka dapat di analisis menggunakan teori semiotika (ilmu tanda). Hal itu dikarenakan teks naskah drama yang begitu puitis. Yang ketiga, menariknya naskah ini sudah diterjemahkan ke dalam bahasa Jepang dengan judul Sakeme oleh Akiko Iwata.

Selain itu teks drama Cabiktelah banyak diadakan penelitian sehingga teks naskah drama ini sangat bermutu dan dari sekian banyak para peneliti lain mengkaji naskah drama Cabik memudahkan peneliti untuk meneliti tanda-tanda pada dialog naskah tersebut. Jadi, tanda-tanda serta makna yang terdapat dalam naskah drama Cabik dalam buku Dalam Tubuh waktu akan diteliti lebih lanjut dengan menggunakan pendekatan semiotik.

Muhammad Ibrahim Ilyas, lahir di Padang, 28 Januari 1963. Dia adalah penggiat seni teater, aktif dalam menulis, dan salah satu seniman yang meraih penghargaan tingkat Nasional. Dan salah satu karya yang meraih penghargaan adalah naskah drama Cabik dalam buku Dalam Tubuh Waktu. Naskah drama Cabik di dalamnya terdapat tanda-tanda simbol dan makna simbolik yang secara utuh (Ilyas,2013:3). 


\section{Ratna Ningsih; Amril Canrhas; Emi Agustina}

Penelitian ini mendeskripsikan tanda-tanda simbol yang terdapat dalam naskah drama Cabik karya Muhammad Ibrahim Ilyas dan mendeskripsikan tanda-tanda simbolik yang diungkapkan melalui tokoh naskah drama Cabik karya Muhammad Ibrahim Ilyas. Penelitian ini diharapkan dapat menambah pengetahuan dan pemahaman mengenai naskah drama, khususnya mengenai tanda dan makna naskah drama. Memberikan sumbangan bermakna terhadap perkembangan ilmu sastra dan seni pertunjukan. Serta diharapkan mampu digunakan oleh pengajar pendidik khususnya Bahasa Indonesia sebagai materi ajar yaitu materi sastra.

Nama lain semiotika adalah semiologi. Keduanya, memiliki pengertian yang sama, yaitu sebagai ilmu tentang tanda. Baik semiotika maupun semiologi berasal dari Bahasa Yunani: semion, yang berarti tanda (Santosa, 2013 : 3).

Bagi Pierce, tanda linguistik merupakan salah satu kategori tanda yang dianggap penting, tetapi bukan tanda yang terpenting. Pierce telah memberikan dasar-dasar yang kuat bagi perkembangan semiotik modern. Karya-karyanya yang tersebar dalam berbagai teks, baru diterbitkan oleh murid-muridnya setelah kematian. Menurut Peirce, tanda adalah sesuatu yang mewakili seseorang atau sesuatu yang lain, dalam hal-hal dan kapasitas tertentu (Noth, 1990 : 42) dalam buku Zaimar.

Simbol merupakan aspek pengkodean fiksi yang khas bersifat struktural. Hal tersebut dilandasi oleh suatu gagasan bahwa makna dapat diformulasikan dari berbagai oposisi biner (binary oppositions) misalnya, seorang anak (dapat) belajar mengetahui perbedaan antara ayah dan ibunya sehingga ia juga dapat belajar bahwa dirinya berbeda atau sama dengan yang lain. Dalam teks verbal, oposisi simbolik semacam ini dapat dikodekan melalui berbagai istilah retorik (Ratih, 2016:4).

\section{METODE}

Metode yang digunakan dalam penelitian ini adalah deskriptif kualitatif. Sebagai penelitian deskriptif, penelitian ini hanya memaparkan yang ada di dalam suatu wacana, tidak mencari hubungan dan tidak menguji hipotesis. Data penelitian ini adalah data kualitatif. Peneliti akan mendeskripsikan tanda-tanda serta menginterpretasikan pesan yang ada di dalam naskah Cabik karya Muhammad Ibrahim Ilyas menggunakan metode semiotik Charles Pierce.

Dipilih sebagai metode penelitian karena semiotik bisa memberikan ruang yang luas untuk melakukan interpretasi terhadap naskah drama sehingga pada akhirnya bisa didapatkan tanda beserta makna yang tersembunyi dalam sebuah naskah drama. Sumber data dalam penelitian ini adalah seperti buku naskah drama Dalam Tubuh Waktu karya Muhammad Ibrahim Ilyas diterbitkan pertama kali oleh Teater Imajinasi 2013, bukubuku semiotik, internet, jurnal, artikel, dan penelitian terdahulu.

Data berupa dialog yang terdapat dalam naskah drama Dalam Tubuh Waktu karya Muhammad Ibrahim Ilyas yang mengandung tanda-tanda simbol semiotik dan terdapat berupa makna. Prosedur penelitian ini adalah sebagai berikut: pertama, membaca naskah drama Cabik karya Muhammad Ibrahim Ilyas. Kedua, mengidentifikasi tandatanda simbol yang terdapat dalam dialog teks naskah drama Cabik karya Ibrahim Ilyas. Ketiga, menganalisis makna dari tanda-tanda simbolik yang terdapat dalam dialog teks naskah drama Cabik karya Muhammad Ibrahim Ilyas. Keempat, menyimpulkan analisis 
makna tanda di setiap babak serta makna keseluruhan simbolik teks naskah drama Cabik karya Muhammad Ibrahim Ilyas.

\section{HASIL DAN PEMBAHASAN}

Data yang diperolah dalam penelitian ini berupa dialog di dalam teks naskah drama Cabik karya Muhammad Ibrahim Ilyas. Naskah drama Cabik karya Muhammad Ibrahim Ilyas menceritakan hubungan cinta tokoh Laki-laki dan Perempuan tetapi dalam keadaan kekecewaan dan keraguan untuk berpisah. Di dalam cerita bukan hanya dua tokoh lakilaki dan perempuan yang terlibat, tetapi di dalam cerita ada berupa dialog " Ting!" yang diperankan tokoh Suara.

Naskah drama yang diberi judul Cabik memiliki makna yang tersirat di dalamnya, sehingga ketika pembaca membaca naskah secara keseluruhan dan secara cermat, maka makna "cabik" akan tersampaikan.

Hubungan rumah tangga antara tokoh Lelaki dan tokoh Perempuan merupakan keadaan hubungan suami dan istri adanya keinginan untuk memiliki seorang anak tetapi belum terwujud yang mengakibatkan menjadi beban sehingga ada keretakan hubungan antara kedua tokoh untuk berpisah tetapi dalam keadaan keraguan untuk tetap bersama atau berpisah. Di setiap awal percakapan sampai puncak perdebatan, selalu terputus dengan suara "Ting!" yang menunjukkan simbol waktu. Jalan cerita di dalam naskah drama Cabik terdapat rangkaian kejadian serta ungkapan yang berulang-ulang tetapi jalan cerita tetap utuh.

1. Identifikasi Tanda-tanda Simbol yang terdapat dalam Teks Naskah Drama Cabik Karya Muhammad Ibrahim Ilyas

Naskah drama 'cabik' pada babak satu dan babak dua diawali dengan tokoh Suara dengan dialog yang hanya berupa simbol bunyi 'ting!'.

Babak satu
SUARA :Ting!
Babak dua
SUARA : Ting!
SUARA : Ting!
(Cabik, 2013: 16-18)

Terlihat seperti instrumen yang memberi jeda pada ketegangan dialog, tetapi bila diamati Suara 'ting!' menjadi pengendali yang lebih besar dan dominan dalam setiap bagian babak satu sampai babak sepuluh. Suara 'ting!' menjadi sebagai pengendali, pemutus, menghambat dan memaksa dua tokoh Perempuan dan Lelaki dalam menggerakkan cerita. Peneliti menganggap suara ting! sebagai simbol, pertama suara tersebut berperan dalam setiap babak alur cerita. Simbol Ting! menjadi seperti waktu setiap perdebatan tokoh lelaki dan perempuan. Kedua, teks naskah drama Cabik merupakan salah antalogi naskah drama karya Muhammad Ibrahim Ilyas yang berjudul Dalam Tubuh Waktu.

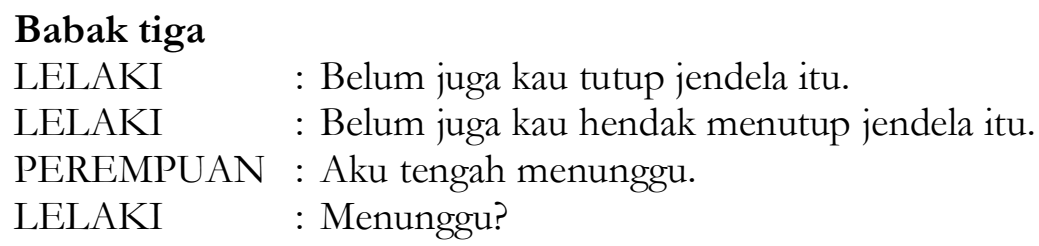


PEREMPUAN : Ya.

(Cabik, 2013: 19-20)

Dialog babak ketiga, kata menunggu dianggap sebagai simbol. Kata menunggu mengharapkan sesuatu akan datang dan terjadi, kata menunggu bisa berarti menunggu seseorang atau sesuatu hal yang perlu ditunggu dengan membutuhkan waktu.

LELAKI : Menunggu entah. Dari kelam yang ada di depanmu?

PEREMPUAN : Segala bermula dari kelam.

(Cabik, 2013:20)

Dialog kelam. Kelam bila diartikan secara harfiah merupakan sesuatu yang gelap. Ada sesuatu hal yang ingin sampaikan tokoh Perempuan merupakan salah satu ungkapan perasaannya dari masa lalu.

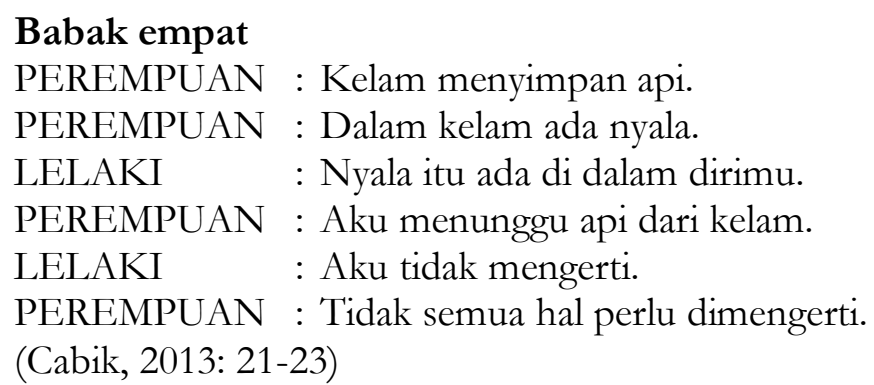

Babak ke empat muncul kalimat kelam menyimpan api. Simbol kelam melambangkan sesuatu yang gelap atau suram serta diartikan masa lalu yang yang dirasakan tokoh perempuan dengan tokoh lelaki penandanya dilihat dari dialog kelam babak ketiga. Simbol api melambangkan panas dan cahaya dari sesuatu yang terbakar. Peneliti beranggapan api sebagai simbol dalam teks naskah merupakan konotasiberupa cahaya harapan yang ditunggu tokoh perempuan.

Simbol nyala yang disampaikan dialog tokoh Lelaki, melambangkan cahaya yang keluar dari api bila terlihat di dalam konteks api dan nyala yang saling berhubungandengan suatu harapan. Cahaya berkaitan dengan api yang ingin ditunggu oleh tokoh perempuan. Kalimat kelam menyimpan api, begitu dominan diungkapkan di dalam naskah drama 'cabik'.

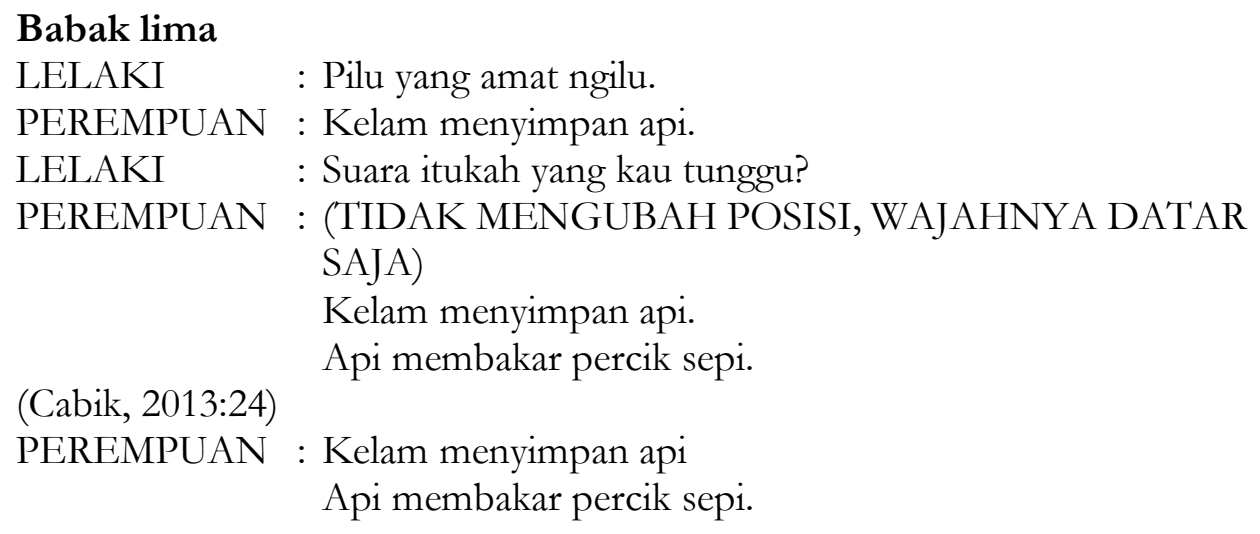




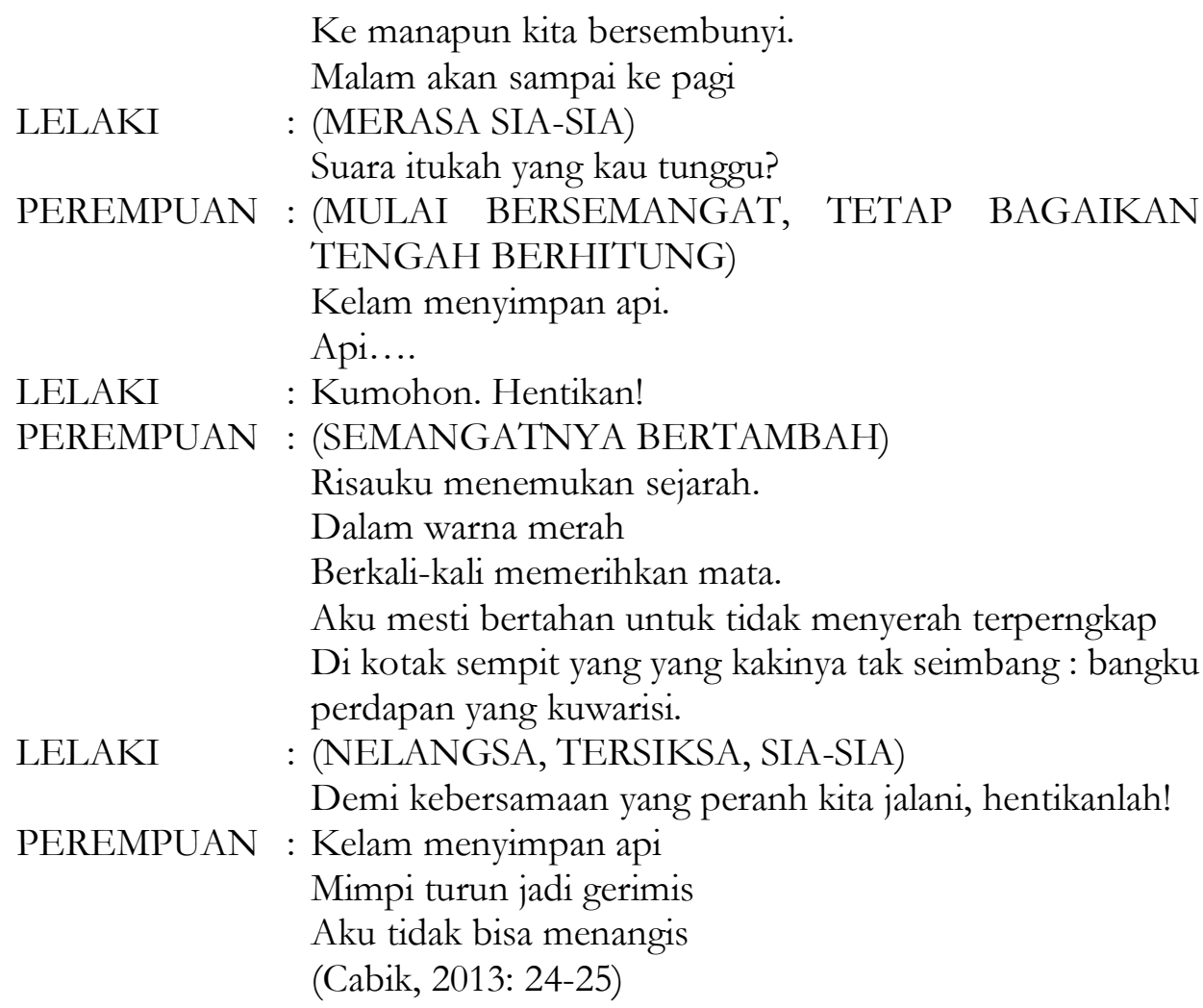

Kelam menyimpan api sesuatu yang gelaptetapi ada api sebagai cahaya yang berasal dari tokoh perempuan berharap dalam kegelapan adanya harapan. Penyebuatan api membakar percik sepi berhubungan dengan kelam menyimpan api, sepi kekosongan dan sunyi berawal akibat dari keinginan mempunyai anak, maka api yang merupakan harapan berharap bisa membakar sepi. Pengulangan kalimat kelam menyimpan api disampaikan lagi oleh tokoh perempuan. Tanda kata kelam sesuatu peristiwa yang begitu 'gelap' terjadi pada tokoh perempuan selama tokoh perempuan menjadi seorang istri.

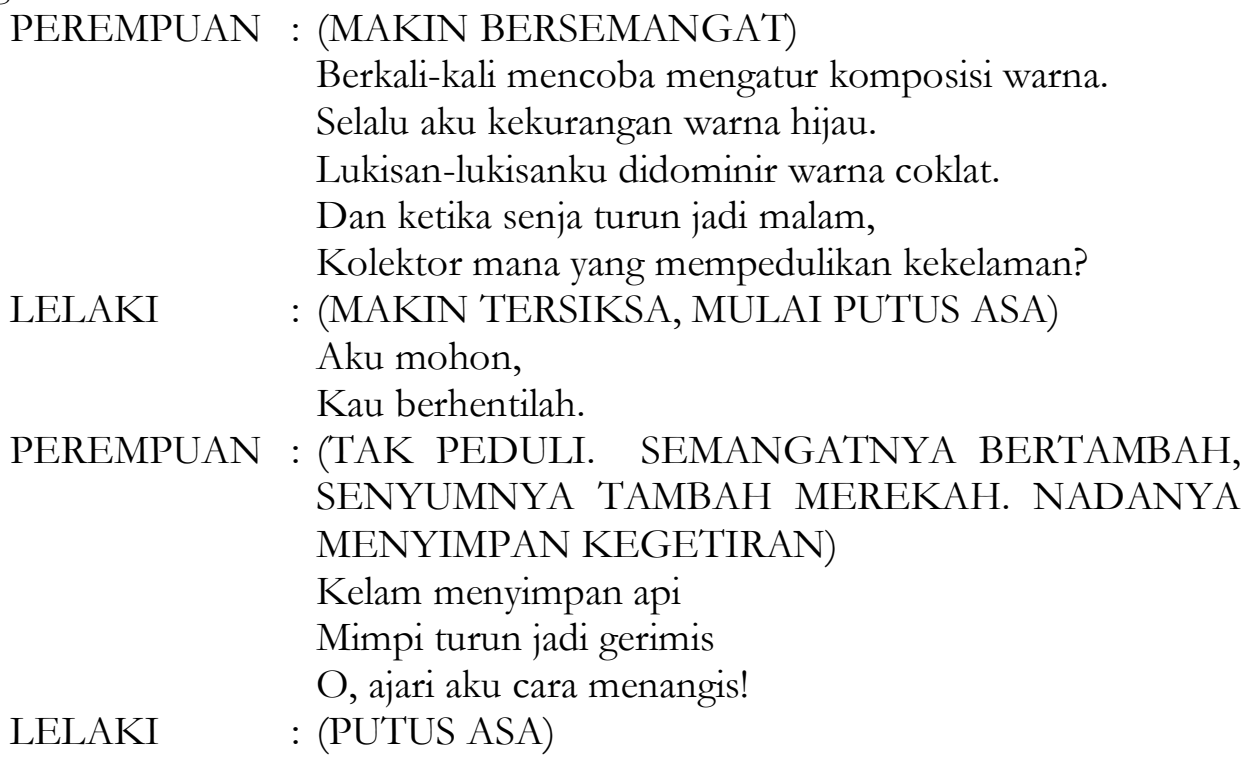


Istriku!

(Cabik, 2013: 26-27)

Simbol warna bijau dalam artian sama dengan warna dedaunan, kesejukan dan keindahan keindahan yang jika digambarkan membawa ketenangan dan kedamaian. Simbol warna coklat berhubungan dengan warna hijau yang diinginkan tokoh perempuan di dalam kehidupannya. Simbol warna cokelat diartikan sesuatu yang gersang dan diibaratkan daun yang layu. Hal itu perempuan mengganggap dirinya hanya didominir warna cokelat tidak ada keindahan dan ketenangan dalam tokoh perempuan.

Warna merah diartikan simbol menggambarkan semangat tetapi dalam konteks berhubungan dengan peristiwa kelam yang telah dialami tokoh perempuan. Lalu, berlanjut dengan peristiwa kelam yang menjadi alasan kemarahan dan kekecewaan yang muncul diingat oleh tokoh perempuan. Simbol memeribkan mata melambangkan yang tampak di depan mata menyusahkan dan tidak meyenangkan bagi tokoh perempuan. Kata mimpi turun jadi gerimis, mimpi diartikan sebagi simbol angan-angan yang didambakan ternyata pupus dan jatuh seperti gerimis hujan yang jatuh ke permukaan.

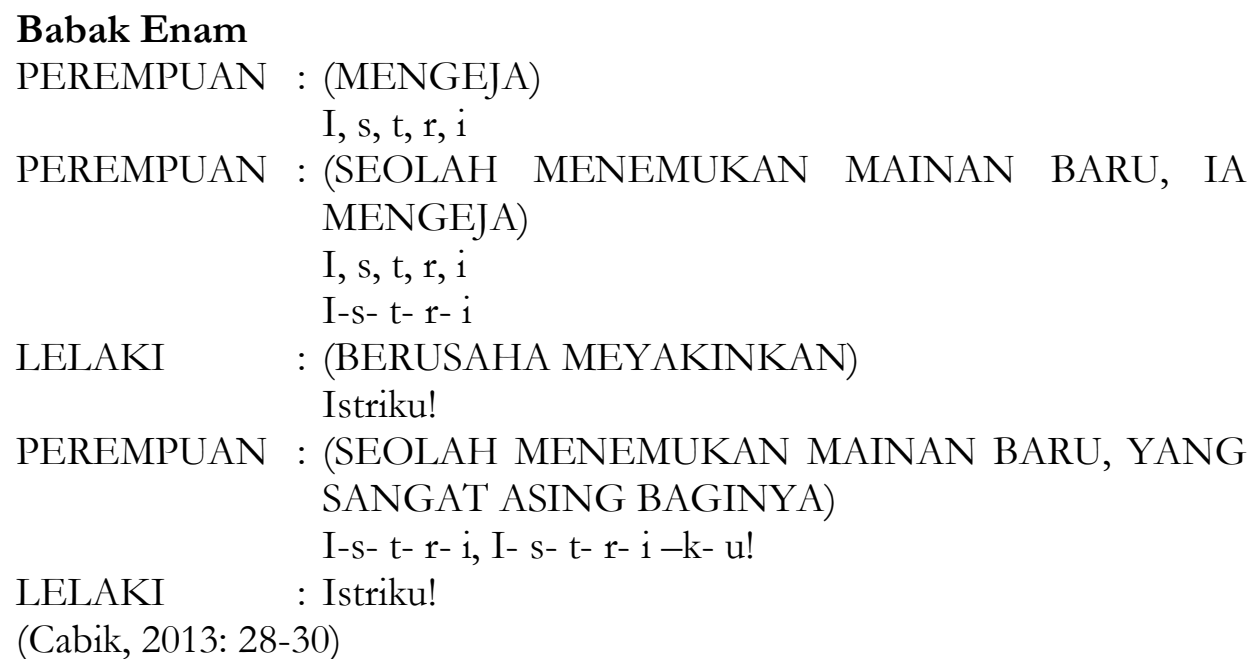

Naskah drama 'cabik' sebelumnya telah dijelaskan merupakan konflik hubungan prahara rumah tangga antara dua tokoh Perempuan dan Lelaki. Terlihat dalam dialog tokoh perempuan seperti mengeja kata yang memiliki makna, Lelaki dan Perempuan mempertanyakan dan berusaha menegaskan posisi yang mengikat mereka sebagai sebagai suami dan istri. Bukan hanya persoalan rumah tangga saja, tetapi juga ada hal lain yang ingin disampaikan dari dialog mengeja huruf dari kata $i-s-t-r-i$.

Dialog $i-s-t-r-i$ yang diungkapkantokoh Perempuanmemiliki makna selama menjadi seorang istri, keseharian yang telah dikorbankan selama menjadi seorang istri dan impian menjadi seorang istri serta berharap kehadiran seorang anak di dalam keluarga. Hal tersebut terlihat di babak ke-tujuh.

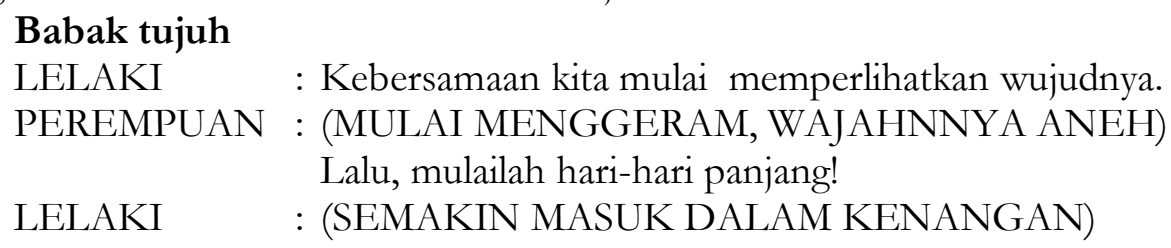


Hari-hari yang akan selalu kukenang, selalu dengan amat senang.

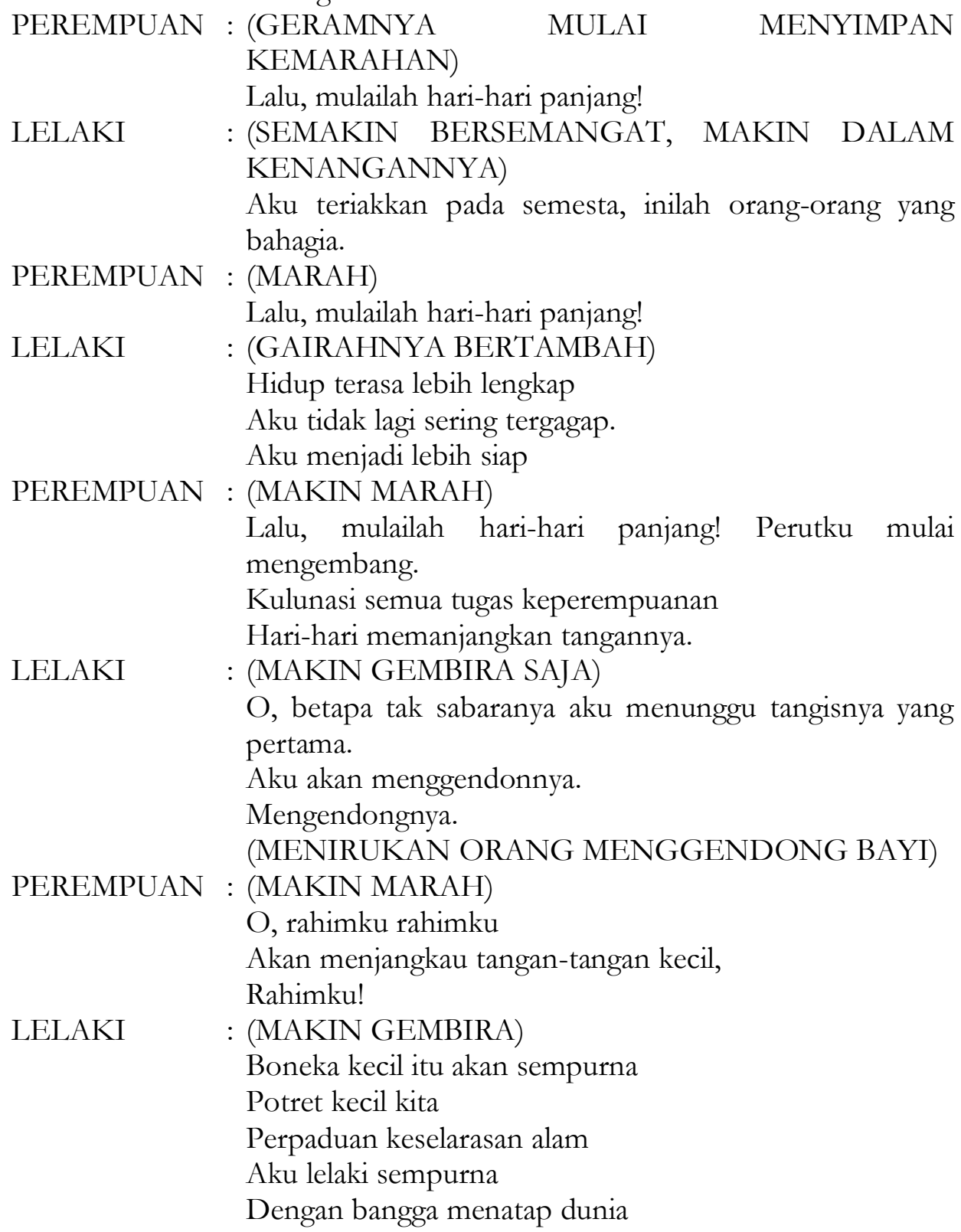

Simbol boneka kecil, merupakan kiasan yang berhubungan dengan seorang anak yaitu bayi yang siap akan dikeluarkan dari rahim tokoh perempuan. Simbol nang, ning,nang, ning, nang, ning, nong! adalah sebuah nyanyian, yang biasa dinyanyikan oleh orang tua kepada anak kecil ketika sedang bermain bersama. Dalam dialog tokoh lelaki berkhayal mempunyai seorang bayi.

Sebelumnya peneliti membahas banyak menemukan tanda-tanda simbol yang terdapat dalam teks naskah drama Cabik karya Muhammad Ibrahim Ilyas. Pada bab ke- tujuh peneliti menganggap di bab ke-tujuh terdapat tanda indeksikalistas.Indeks sebagai penanda dan petandanya yang memiliki sifat mengisyaratkan sesuatu. 
Terjadinya suatu peristiwa pasti ada hubungan dengan peristiwa lainnya atau sebab akibat.

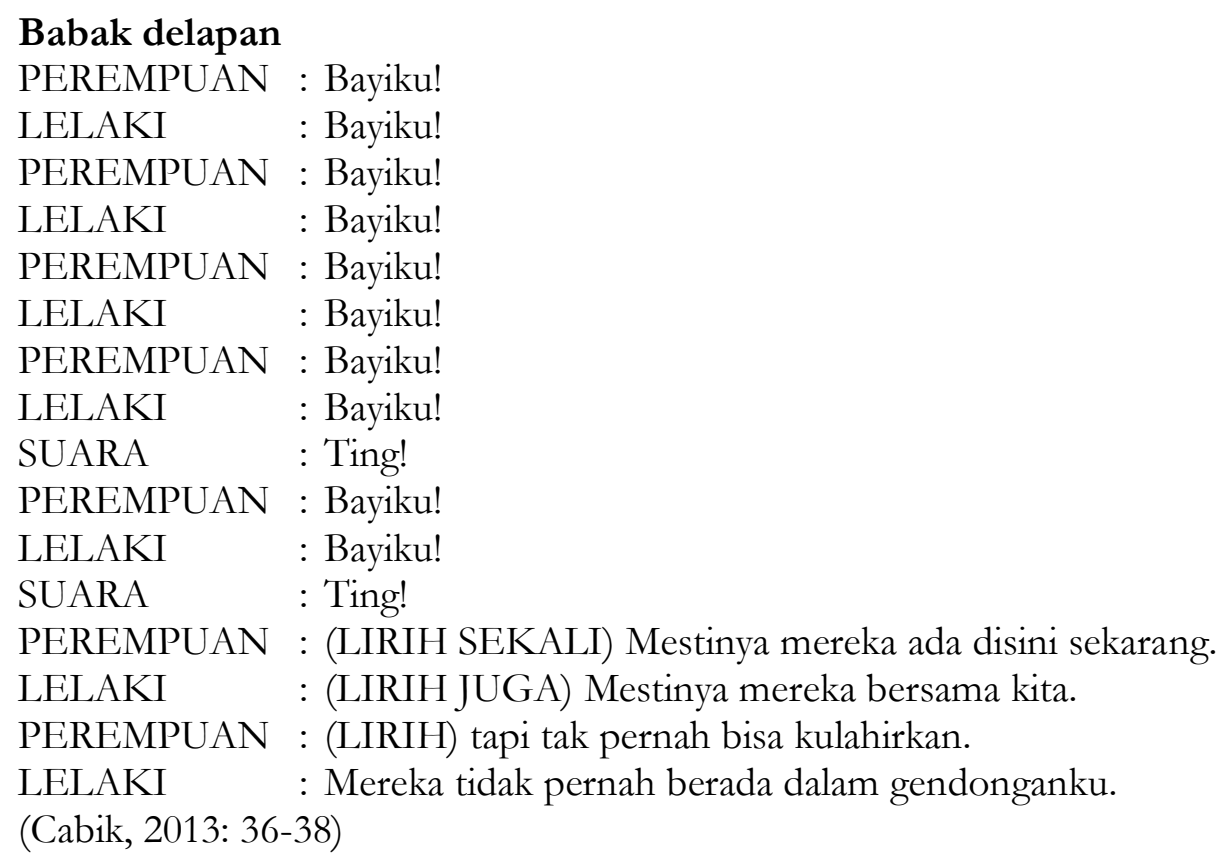

Cerita naskah drama Cabik menceritakan prahara atau keretakan rumah tangga, tentu ada penanda yang sebagai pendukung bahwa peristiwa keretakan antara tokoh perempuan dan tokoh lelaki yaitu mengharapkan kehadiran seorang anak. Indeks sesuatu yang fungsinya sebagai penanda yang mengisyaratkan petandanya. Peneliti menganggap dialog yang membicarakan persoalan bayi sebagai indeks, karena memiliki hubungan dengan peristiwa yang lama menunggu kehadiran seorang anak, yang menimbulkan hubungan yang terasa "Cabik" yang menjadi sebagai judul teks naskah drama Cabik karya Muhammad Ibrahim Ilyas.

Penjelasan peristiwa pada babak-babak sebelumnya, persoalan bayi merupakan salah satu sebab akibat kekelaman yang menjadi prahara dalam rumah tangga tokoh perempuan dan tokoh lelaki. Dilihat dari dialog sebelumnya babak ketujuh tokoh perempuan meluapkan emosi yang digambarkan dengan api berharap akan sebuah cahaya yang datang berupa harapan.

Selanjutnya, simbol bibitku yang diucapkan oleh tokoh Lelaki dan simbol rabimku yang diucapkan tokoh perempuan, bibit merupakan benih dalam arti sesuatu yang akan dikembangkan di dalam rahim. Bibit berkaitan dengan kata bayi, karena bibit yang dimaksud adalah generasi yang akan siap dirahimi oleh tokoh Perempuan. Rabim yang merupakan kantong selaput perut tempat janin (bayi) tokoh perempuan. Dialog rabimku membunub bibitmu, tokoh perempuan yang memiliki rahim seakan-akan merasa bersalah karena belum bisa mewujudkan generasi yang seharusnya siap untuk dirahimi lalu siap untuk dilahirkan.

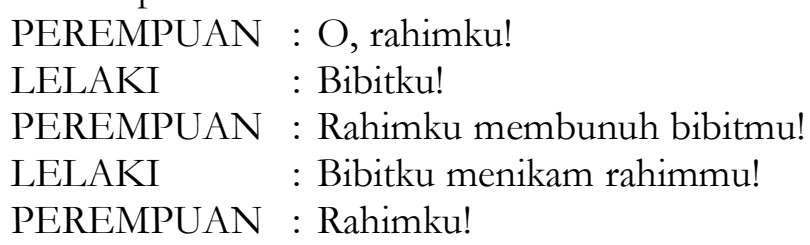




\author{
LELAKI : Bibitku! \\ (Cabik,2013: 38)
}

Naskah drama Cabik karya Muhammad Ibrahim Ilyas menggambarkan Lelaki dan Perempuan menginginkan seorang bayi yang telah lama dinantikan. Tetapi karena keinginan itu tidak terwujud mulailah konflik Lelaki dan Perempuan yang ingin berpisah tetapi dalam keadaan keraguan.

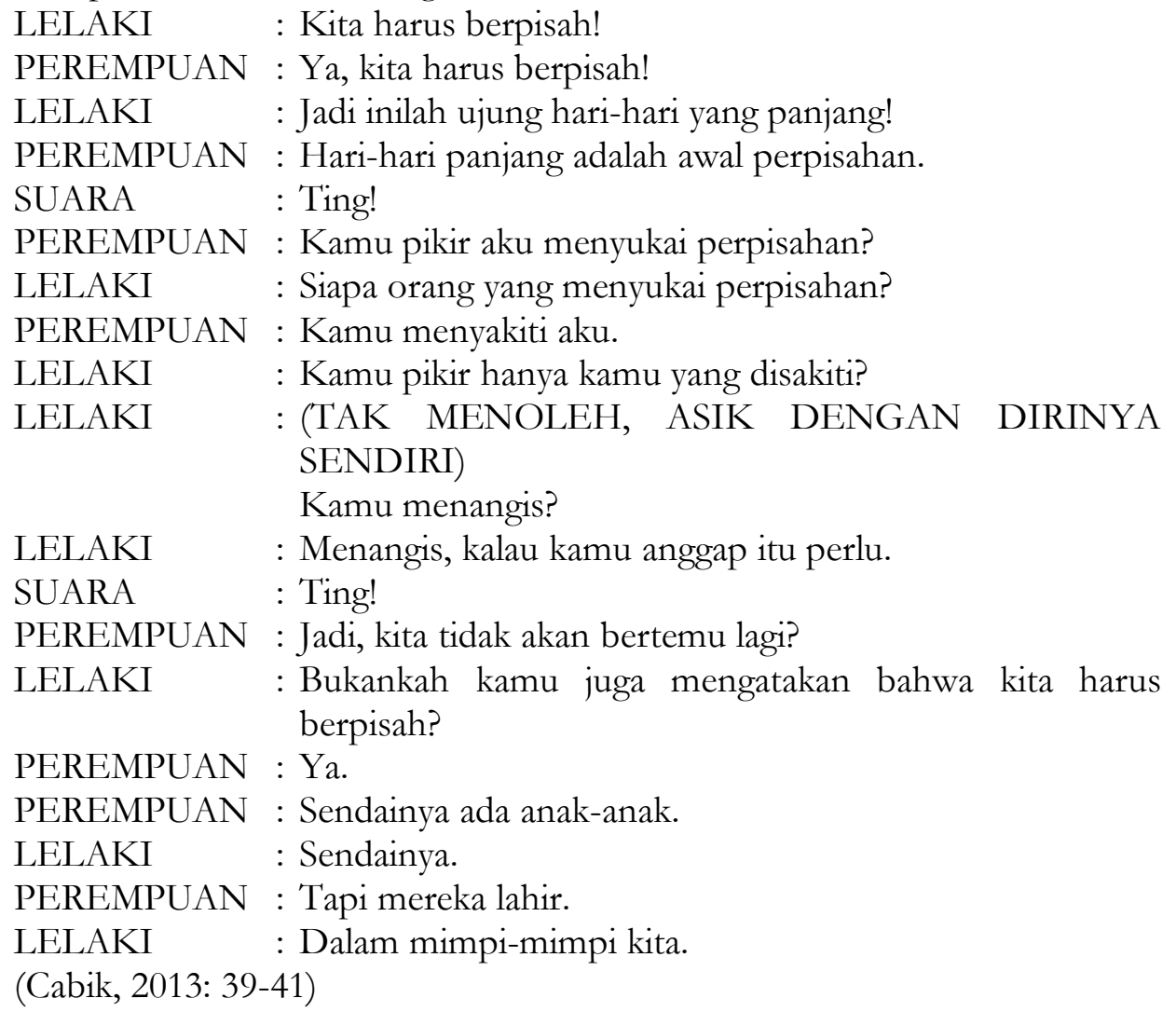

Penjelasan peristiwa sebab-akibat yang telah disampaikan peneliti sebelumnya, tampak tokoh perempuan dan lelaki mengalami keretakan hubungan serta berencana ingin berpisah. Cerita naskah drama Cabik hubungan prahara atau keretakan rumah tangga, tentu ada penanda yang mendukung peristiwa keretakan antara tokoh perempuan dan tokoh lelaki. Faktor lain yang fungsinya sebagai penanda yang mengisyaratkan petandanya, peneliti menganggap dialog yang membicarakan persoalan bayi sebagai salah satu faktor kemunculan rasa 'cabik', karena memiliki hubungan dengan peristiwa yang lalu yaitu kelam, yang menimbulkan "cabik" yang menjadi sebagai judul teks nskah drama Cabik karya Muhammad Ibrahim Ilyas.

\title{
Babak sembilan
}

LELAKI : Jadi, kita akan berpisah?

PEREMPUAN : Bukankah kita sudah sepakat?

PEREMPUAN : Kita akan menganggap bahwa kita tidak pernah bertemu?

LELAKI : Tidak

PEREMPUAN : Lalu?

LELAKI : Kita melangkah sendiri-sendiri, menghadapi hari baru

PEREMPUAN : Dan kita tidak akan pernah bertemu lagi? 


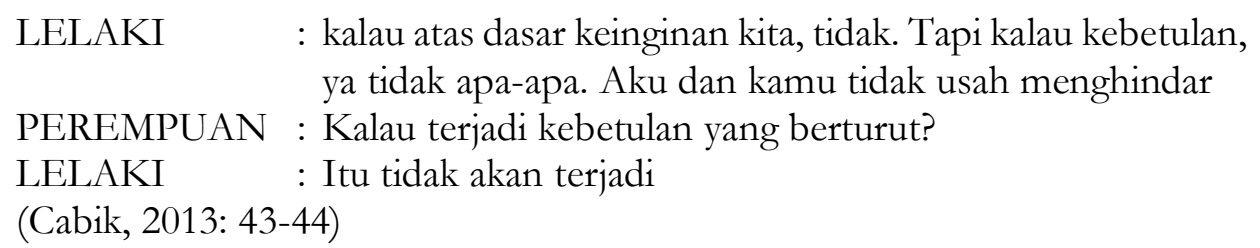

Dialog di atas naskah drama Cabik karya Muhammad Ibrahim Ilyas menggambarkan Lelaki dan Perempuan menginginkan seorang bayi yang telah lama dinantikan. Tetapi karena keinginan belum juga terwujud mulai terlihat jelas hubungan yang 'cabik' antara Lelaki dan Perempuan menginginkan perpisahan tetapi masih dalam keadaan keraguan.

$\begin{array}{ll}\text { PEREMPUAN } & : \text { Apakah kita tidak saling melukai? } \\ \text { LELAKI } & \begin{array}{l}\text { Luka akan menganga lebar, bila kebersamaan ini kita } \\ \text { lanjutkan }\end{array} \\ \text { PEREMPUAN } & : \text { Tapi pisau perpisahan amat tajamnya } \\ \text { LELAKI } & : \text { Ya } \\ \text { PEREMPUAN } & : \text { Dengan sadar melukai diri sendiri? } \\ \text { LELAKI } & \text { : Kadang kita mesti dan perlu melukai diri sendiri. Agar } \\ & \text { tahu persis apa luka itu sesungguhnya, untuk mengerti } \\ & \text { separah apa rasa sakit bisa mencengkeramkan kukunya di } \\ & \text { darah kita, agar merasakan sejauh mana kita mencoba } \\ & \text { mengerti. } \\ \text { PEREMPUAN } & : \text { Itu bentuk lain dari bunuh diri } \\ \text { LELAKI } & : \text { Tergantung } \\ \text { PEREMPUAN } & : \text { Tergantung apa? } \\ \text { LELAKI } & : \text { Bagaimana kita mengartikannya } \\ \text { LELAKI } & : \text { Kita berpisah? } \\ \text { PEREMPUAN } & : \text { Kita berpisah? } \\ \text { PEREMPUAN } & : \text { Kita mengalah pada luka? } \\ \text { LELAKI } & : \text { Kita mengalahkan diri sendiri! } \\ \text { (Cabik, 2013: } 45-46)\end{array}$

Simbol perpisahan dan luka, perpisahan dalam naskah drama 'cabik' merupakan perceraian, sesuatu hal berpisah atau terpisah. Simbol luka, luka bila diartikan secara harfiah adalah belah pada kulit akibat dari benda tajam di dalam konteks luka. Kedua kata tersebut berhubungan dengan 'cabik'.

Babak sepuluh

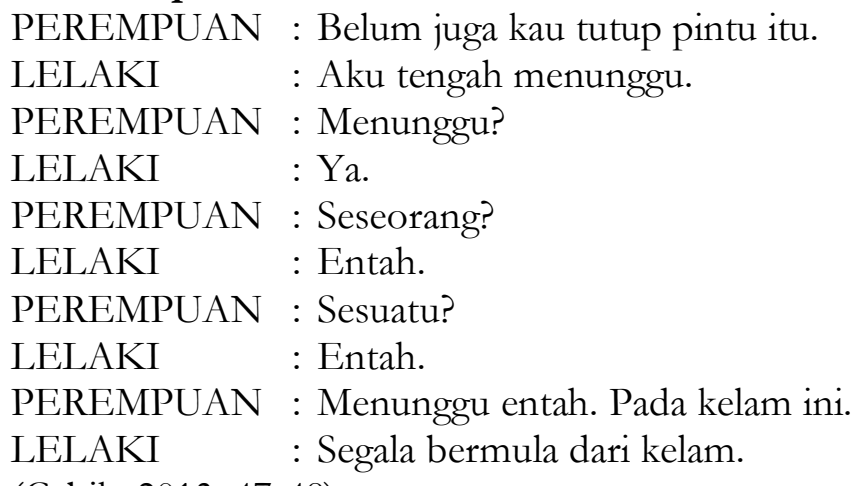

(Cabik, 2013: 47-48) 
Babak sepuluh ditemukan kesamaan dialog menunggu pada babak tiga, hanya saja ada pergantian yang bertanya dan menjawab. Siklus hubungan percintaan dan menunggu harapan keinginan mempunyai anak serta perdebatan tanpa usai.

2. Makna simbolik yang terdapat dalam naskah drama Cabik karya Muhammad Ibrahim Ilyas

Cabik diartikan secara umum adalah robek atau koyak, artian robek atau koyak 'lembaran' cerita cinta hubungan rumah tangga antara tokoh perempuan (istri) dan tokoh lelaki (suami) yang memiliki konflik batin di dalam diri mereka untuk memilki seorang anak. Perpisahan pun menjadi salah satu keputusan, tetapi tokoh perempuan dan tokoh lelaki dalam keadaan keraguan berharap sesuatu yang 'cabik' dapat diperbaiki.

Memiliki sebuah keluarga merupakan sumber kebahagian yang luar biasa. Ketika mendapatkan pasangan yang saling mendukung dan tidak mementingkan diri sendiri, maka disitulah rasa bahagia yang tiada tara apalagi ditambah dengan kehadiran sosok seorang anak sebagai penerus, pewaris, dan penerus yang melanjutkan generasi berikutnya.

Penjelasan makna simbolik naskah drama Cabik berdasarkan simbol-simbol yang telah ditemukan yaitu: babak ketiga yang diugkapkan oleh tokoh perempuan kata menunggu, diartikan menandakan menantikan sesuatu yang seharusnya datang atau terjadi. Berharap kehadiran seseorang yang begitu kuat pengaruhnya di dalam suatu keluarga.

Babak ke-empat ungkapan Aku menungu api dari kelam adalah sesuatu cahaya, harapan, penyemangat dan salah satu pendukung kehidupan untuk tokoh perempuan. Keinginan yang ditunggu tokoh perempuan dari kegelapan adalah ungkapan api yang bisa menjadi penerang dan penyemangat hidup serta memberi ketenangan di dalam keluarga. Kelam merupakansesuatu yang begitu gelap berharap dapat ditembus dengan api. Maksudnya adalah, kelam sesuatu hal atau peristiwa yang tidak begitu mengenakkan atau ketidakbahagiaan telah terjadi pada kedua tokoh, maka berharap adanya api bisa membantu hubungan antara tokoh perempuan dan tokoh lelaki menjadi bahagia tanpa adanya kesedihan.

PEREMPUAN : Kelam menyimpan Api.

PEREMPUAN : Dalam kelam ada nyala.

LELAKI : Nyala itu ada di dalam dirimu.

PEREMPUAN : Aku menunggu api dari kelam.

(Cabik, 2013: 23)

Ungkapan nyala itu ada di dalam dirimu, artinya adalah adanya cahaya di dalam tokoh perempuan. Cahaya penerang rumah tangga adalah seorang perempuan (istri), peranan seorang istri begitu kuat dalam hubungan berumah tangga. Ketika suami mengalami kegundahan, istri lah yang dapat menenangkannya dan ketika lelaki mengalami keterpurukan, istri lah yang dapat menyemangatinya.Ungkapan kata Sepi, diartikan sesuatu kekosongan yang dirasaan tokoh perempuan selama berumah tangga dan berharap api dapat membakar sedikit kokosongan di dalam keluarga.

PEREMPUAN : (TIDAK MENGUBAH POSISI, WAJAHNYA DATAR SAJA)

Kelam menyimpan api. 
(Cabik, 2013: 25)

Api membakar percik sepi.

Dialog selanjutnya pada babak ke-lima tokoh perempuan menjelaskan kehidupan yang dialaminya dan menghubungkan kehidupan tokoh perempuan dengan warna dan alam.

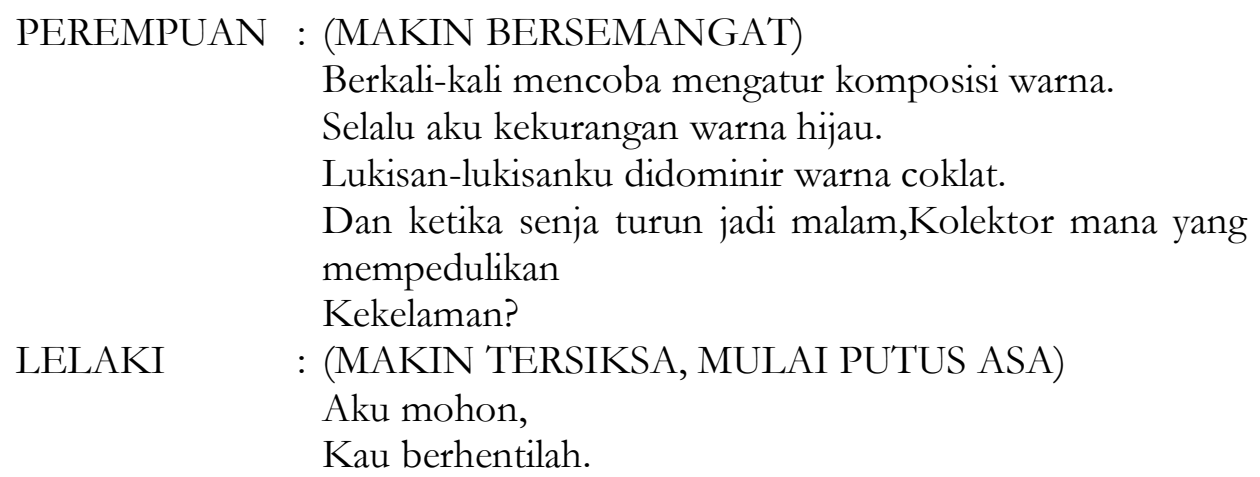

(Cabik, 2013: 26-27)

Makna tesirat yang terlihat pada dialog tokoh perempuan menghubungkan warna, benda, dan alam. Kata warna ketika dilihat dari kata sebelumnya tokoh perempuan mencoba mengimbangi keadaan mengatur kehidupan. Warna memiliki kekuatan untuk menyampaikan dan mengkomunikasikan arti dan pesan tanpa dijelaskan secara langsung. Yang dimaksud bisa berupa kehidupan, karena setiap kehidupan memilki warna yang berbeda-beda. Tokoh perempuan merasa kekurangan warna hijau, warna bijau memiliki arti sebagai alam, kesejukan dan sesuatu yang berhubungan dengan keindahan. Warna bijau gambaran kehidupanyang yang diinginkan tokoh perempuan. Tetapi warna coklat yang dijelaskan dalam dialog lebih banyak di kehidupan tokoh perempuan. Warna coklat diartikan sesuatu yang sederhana, bila dikaitkan dengan kehidupan warna coklat terlihat gersang dan daun yang layu. Relevansinya dengan kehidupan tokoh perempuan yang didapat adalah kesedihan dan kekecewaan. Kolektor mana yang mempeulikan kekelaman? artinya menjelaskan tidak akan ada yang memilih dan menjalani hidup dalam kekecewaan serta dalam keadaan yang tidak bahagia.

Babak ke-enam berulang-ulang tokoh perempuan mengungkapkan kata istri, terlihat seperti kehilangan jati diri dan mempertanyakan seperti apa makna kata istri.

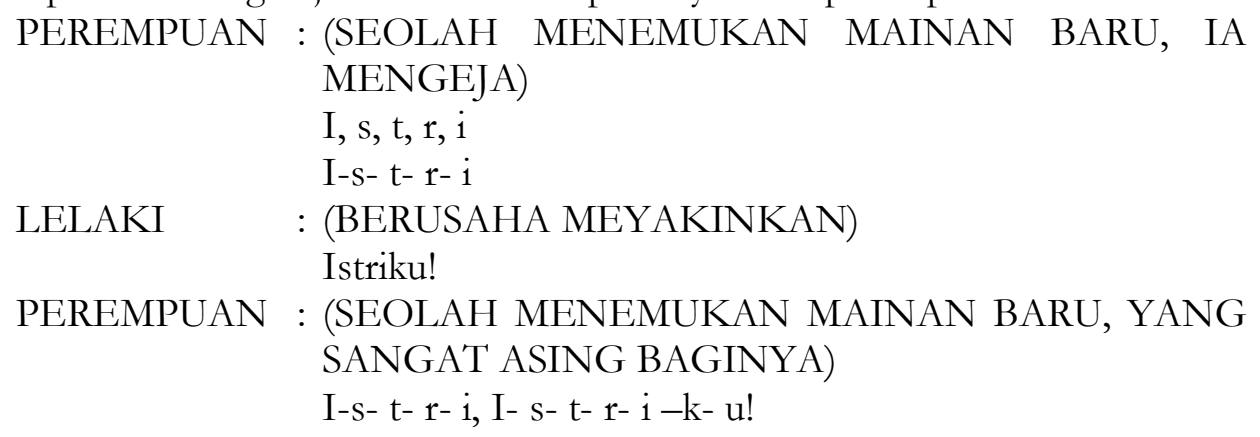

(Cabik, 2013: 28-30)

Makna tersirat kata istri yang berulang-ulang diucapkan tokoh perempuan mempertanyakan pengertian dari kata istri terhadap tokoh lelaki. Tokoh lelaki berusaha memberi penjelasan, tetapi tokoh perempuan merasa tidak cukup 
sebagaimana yang telah dijelaskan oleh tokoh lelaki. Tokoh lelaki hanya menjelaskan bahwa arti kata istri sebatas seorang perempuan yang didapatkan setelah menikah. Simbolik istri atau seorang wanita begitu banyak menyimpan makna salah satunya peranan wanita dalam keluarga yaitu, wanita sebagai seorang istri, sebagai seorang ibu, dan di luar hal itu adanya peran wanita dalam masyarakat, kaum dan negara.

Seperti hal yang diketahui oleh peneliti pengarang naskah drama Cabik berasal dari daerah Sumatera Barat, Padang. Bila dihubungkan menurut orang Minangkabau, bahwasanya perempuan sebagai simbol sebagaimana perannya di dalam masyarakat atau kaum yang baik, dapat terlihat baiknya perempuan di dalam masyarakat, kaum atau negara dan begitu sebaliknya. Karena peran seorang wanita dalam keluarga dan masyarakat merupakan peran yang sangat penting menjadi seorang ibu serta sekaligus membangun generasi-generasi yang baik.

Hadirnya perasaan 'cabik' ketika tujuan membuat lembaran cerita keluarga yang bahagia dalam pernikahan serta membangun rumah tangga dan memiliki keturunan, tetapi lembaran cerita yang diharapkan belum terwujud hanya sebatas khayalan. Maknanya adalah dalam sebuah rumah tangga, kehadiran anak adalah berkat yang istimewa. Kehadiran anak-anak dalam keluarga merupakan sarana pelengkap kepribadian ayah dan ibu (suami dan istri). Hadirnya seorang anak, membuat keluarga selalu bahagia dan hubungan suami istri semakin erat. Kehadiran anak juga dapat menghilangkan masalah yang mengganggu keharmonisan sepasang suami istri. Memiliki Bayi atau anakdi dalam keluarga kekuatan yang begitu besar dan berperan penting dalam suatu generasi dan sosok kecil yang mampu mengahantarkan tokoh perempuan dan tokoh lelaki pada suasana yang sangat jauh dari kesedihan begitupun sebaliknya. Terlihat pada ungkapan dibawah ini.

PEREMPUAN : Bayiku!

LELAKI : Bayiku!

PEREMPUAN : (LIRIH SEKALI) Mestinya mereka ada disini sekarang.

LELAKI : (LIRIH JUGA) Mestinya mereka bersama kita.

PEREMPUAN : (LIRIH) tapi tak pernah bisa kulahirkan.

LELAKI : Mereka tidak pernah berada dalam gendonganku.

(Cabik, 2013: 37-38)

Seorang anak ternyata bisa menentukan hubungan keharmonian rumah tangga. Tokoh perempuan dan lelaki merasa kecewa dari yang telah dialami serta mengambil keputusan untuk berpisah. Berikut kutipan betapa berharapnya tokoh perempuan dan tokoh lelaki mempunyai seorang anak sehingga mengingikan perpisahan:
LELAKI : Kita harus berpisah!
PEREMPUAN : Ya, kita harus berpisah!
LELAKI : Jadi inilah ujung hari-hari yang panjang!
PEREMPUAN : Hari-hari panjang adalah awal perpisahan.
(Cab, 2013: 39)

Perpisahan seolah menjadi keputusan yang tepat karena tidak siap mengadapi keadaan. Makna tersirat menunjukkan tanpa pertemuan tidak akan pernah mengerti dan menghargai kebersamaan, tanpa perpisahan tidak akan pernah tahu betapa berartinya kehadiran sosok seseorang. Perpisahan di dalam cerita, dengan adanya perpisahan untuk bisa memaafkan serta memaknai arti merindu yang sesungguhnya. Hubungan rumah tangga yang bisa menjadi lembaran cerita bahagia menjadi terkoyak 


\section{Ratna Ningsih; Amril Canrhas; Emi Agustina}

atau 'cabik'. Tokoh lelaki dan tokoh perempuan mencoba mengambil keputusan untuk saling melupakan, tetapi tokoh lelaki dan tokoh perempuan masih saling mencintai dan membutuhkan waktu untuk berpisah. Sebab perpisahan membuat kemurungan, kesedihan serta luka perasaaan semakin menganga dan membesar.

Akhir cerita naskah drama, ungkapan kata menunggu kembali diungkapkan seperti awal (babak ke-empat) diungkapkan kembali di akhir cerita. Menurut intrepretan peneliti bahwa makna menunggu berhubungan dengan waktu yang masih perlu dipikirkan untuk keputusan berpisahan akibat dari lembaran cerita kehidupan rumah tangga yang tidak sesuai dengan harapan hingga menimbulkan rasa kecewa dan kesedihan berharap cahaya dari api (harapan) yang dinantikan dapat terwujud berharap waktu bisa menjawab semua dari lembar persoalan-persoalan cerita peristiwa yang kelam. Dilihat dari tokoh lelaki masih mengharapkan sesuatu, kemungkinan dengan menunggu dan adanya waktu dapat memperbaiki lembaran peristiwa yang kelam tidak berujung pada perpisahan atau perceraian.

\section{PENUTUP}

Penanda yang menandakan bahwa makna 'cabik' tersebut muncul dilihat tanda-tanda simbol seperti kata dan kalimat yang begitu dominan disebutkan di dalam naskah .

Tanda-tanda simbol yang terdapat di dalam naskah drama Cabik karya Muhammad Ibrahim Ilyas begitu dominan ditemukan seperti penyebutan kata dan kalimat yaitu: ting!, menunggu, kelam menyimpan api, api membakar percik sepi, dalam kelam ada nyala, bayi, perpisahan, dan luka.

Makna simbolik yang terdapat dalam naskah drama Cabik, menjelaskan tokoh perempuan dan tokoh lelaki mengalami hubungan cerita cinta dan prahara rumah tangga yang ingin berujung pada perpisahan tapi dalam keraguan serta membutuhkan waktu untuk bisa dapat memperbaiki keadaan seperti semula agar lembaran-lembaran cerita begitu kelam dapat ditembus dengan cahaya api (pengharapan) yang begitu diharapkan tokoh Lelaki dan tokoh perempuan.

Berdasarkan uraian dan pembahasan di atas terdapat beberapa saran yaitu:

1. Penelitian terhadap Naskah Drama Cabik ini diperlukan memperhatikan dan memahami kata serta kalimat yang ada di dalam karya sastra naskah drama, karena pengarang setidaknya memasukkan tanda-tanda simbol serta terdapat pula makna tersurat maupun tersirat.

2. Penelitian terhadap Naskah Drama Cabik ini diharapkan dapat dijadikan bahan perbandingan bagi penelitian selanjutnya untuk mengupas lebih dalam mengenai memaknai simbolik yang terdapat di dalam naskah drama.

\section{DAFTAR PUSTAKA}

Aminuddin. (1988). Semantik. Bandung: C.V. SINAR BARU

Hasanuddin, W. (1997). Drama. Bandung: Angkasa.

Ilyas, M, Ibrahim. 2013. Dalam Tubub Waktu. Padang: Teater Imjinasi.

Kartini. 2017. Analisis Novel 5 CM Karya Donny Dirgantoro Dengan Pendekatan Semiotik. Bengkulu: Universitas Bengkulu. 
Makna Simbolik dalam Naskah Drama Cabik Karya Muhammad Ibrahim Ilyas...

Kartika, Yulia. 2012. Analisis Semiotika Teks Drama Kau Tunggu Siapa Nilo Karya Wisran Hadi. Padang: Universitas Negeri Padang.

Littlejhon, W. S. (2009). Teori Komunikasi Theories of Human Communication edisi 9. Jakarta: Salemba Humanika.

Ratih, Rina. (2016). Teori dan Aplikasi Semiotik Michael Riffaterre. Yogyakarta: Pustaka pelajar.

Rokhmansyah, A. (2014). Studi Dan Pengkajian Sastra. Yogyakarta: GRAHA ILMU.

Santosa, Puji. (2013). Ancangan Semiotika dan Pengkajian Susastra. Bandung : Angkasa.

Semi, M. A. (1989). Kritik Sastra. Bandung: Angkasa.

Zaimar, Okke. Kusuma. (2014). Semiotika dalam Analisis Karya Sastra. Depok : PT KOMODO BOOKS.

Zoest, Aart. v. (1993). Semiotika. Jakarta : Yayasan Sumber Agung. 